\section{'Dying': what medicine can learn from fiction}

\author{
John Launer
}

Many medical schools now run courses in literature as part of their medical humanities curriculum. Their aim is to broaden students' understanding of lived experience, which is often conveyed more fully in great works of fiction than in scientific texts. In order to make such learning appear more relevant, the reading lists often include works written by physicians, giving accounts of illness and medical care, especially in the form of short stories. Fortunately there have been several doctors who became famous for this kind of writing. These include the British author Somerset Maugham, ${ }^{1}$ the American general practitioner William Carlos Williams, ${ }^{2}$ and perhaps the greatest short story writer of all time - the Russian playwright and public health physician Anton Chekhov. ${ }^{3}$ If you are not already familiar with these three writers, I strongly recommend dipping into any of their story collections.

There is one other doctor who is far less well-known, but who wrote at least one masterpiece that all students and medical practitioners should read - especially those working with the terminally ill. His name was Arthur Schnitzler (figure 1). He was an Austrian author and playwright who lived in the late nineteenth and early twentieth centuries, during the great flourishing of arts and sciences in Vienna. His contemporaries included Sigmund Freud, the composer Gustav Mahler and the painter Gustav Klimt. Schnitzler's father was an eminent ear, nose and throat surgeon. Schnitzler himself qualified in medicine at Vienna University in 1885 and went on to combine a career as a physician with writing plays, novels and short stories, until success as a dramatist allowed him to give up his medical practice. Although married with two children, he led the life of a libertine. Some of his work was regarded as pornographic in its time, although it was probably unobjectionable by modern standards. It was dismissed as 'Jewish filth' by the Nazis and after his death it was banned under their race laws. His writing is in fact characterised by an acute sensitivity to

Correspondence to Dr John Launer, Health Education England, London WC1H 5DN, UK; johnlauner@aol.com

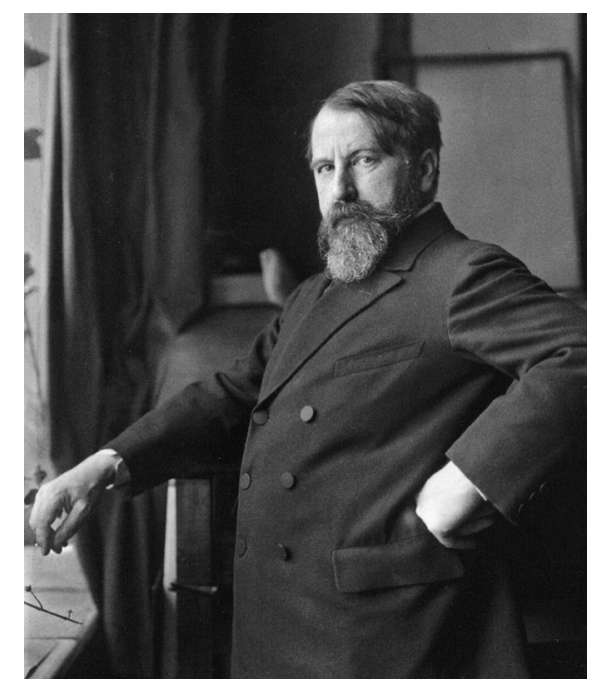

Figure 1 Arthur Schnitzler 1862-1931. Image from Wikipedia.

psychological nuances, which led Freud to praise him for having learnt through intuition and introspection, everything that Freud himself confessed he had to unearth through laborious work on other persons.' His works later inspired classic movies including Max Ophüls' 'La Ronde' and Stanley Kubrick's 'Eyes Wide Shut'.

In his early thirties, while still practising as a doctor, Schnitzler wrote an extraordinary work called simply 'Dying' (Sterben in the original German). ${ }^{4}$ It is a novella - essentially a long short story or very brief novel, that takes only a couple of hours to read. Very little happens in terms of action during the 8 or 9 months covered by the story, and it will scarcely spoil anything for the reader to know what happens in advance.

\section{A MAN DIES}

The plot can be summarised in three words: a man dies. Just before the book starts, a young man called Felix has learnt from a professor of medicine that he will die within a year. His disease is never named, but it would have been obvious to readers that it was tuberculosis, which was incurable at the time. Felix breaks the news to his girlfriend Marie, and confronts his local doctor Alfred, who is a personal friend and has concealed the truth from him. Felix and Marie travel to the countryside for a few months of rest.
They then return to Vienna, spending several days in Salzburg on the way back, during a singing festival. Within a couple of months at home, Felix becomes much weaker, and they decide to travel to a village in the mountains - where he dies the following day. The list of other characters is almost as sparse as the plot: mainly servants and passers-by. The professor who informed Felix that he was dying never appears in person, although half way through the story, Felix learns that the man has suddenly died himself: an instant of irony that is almost the only unexpected drama throughout.

The reason why such a simple and uneventful story is so gripping is its depiction of each person's feelings during the months that Felix's death inexorably approaches. Schnitzler not only reports the couple's conversations but also their inner thoughts, as these alter from moment to moment and day to day in response to Felix's deteriorating health and each other's reactions. His style in some ways resembles the 'stream of consciousness' method used by other contemporaries like James Joyce. On any page, the mood of each character can change from elation to despair, mania to apathy, or from intense mutual love to envy and hatred. Marie's immediate reaction to Felix's terrible news is to declare she will kill herself when he dies: a resolve that then shifts constantly between regretting her promise, guilt, a belief that he will recover, hope for his rapid demise so she can be free, and desperation at the thought of life without him. For his part, Felix moves at different times between the desire to liberate his girlfriend by going away on his own, transient optimism that a miracle recovery will occur, a pathetic need for Marie's constant presence, and murderous jealousy at her own good health, accompanied by a wish to hold her to her suicidal promise. He even imagines strangling her, and on one occasion he feebly attempts to do so. Their sexual feelings mirror these continually changing emotions. For a short time, they are overcome by restored sexual passion, but at other times Marie either toys with the notion of future relationships or studiedly avoids thinking about the possibility.

\section{STATES OF MIND}

As Schnitzler recounts them, all states of mind appear to contain their opposites, or the potential to give rise to them at any moment. Here, for example, are Marie's 


\section{On reflection}

thoughts as she lies in bed one night, while feigning sleep and pretending to be unaware that Felix is watching her:

'She wants to do more for him, she thinks, to give her best, the highest that she can. If she promised to kill herself on his grave, he'd die doubting whether she would really do it. Die with him - no, she will die before him. When he asks, she will have the strength to say, "Let's bring this torment to an end! We'll die together, and we'll die now!" And even as this idea intoxicated her, she saw the woman whose picture had appeared to her just now - hurrying over the fields with the morning wind caressing her, running away towards life and joy, and saw that it was herself, a despicable, vile figure.'

Schnitzler's observation of the range of human feelings, with all their ambiguities and contradictions, is precise, unflinching and above all grown-up. There is nothing straightforward or formulaic in the experiences that Schnitzler describes and exposes us to as readers. The characters each undergo gradual transitions in the course of the narrative, but there are no glib 'stages' of anger, grief and resignation, nor any sense that human emotions come easily packaged as one of these or another. To read 'Dying' may not be a comfortable experience, but is a perfect antidote to the idea that you can learn about the mind, relationships, illness, dying or the human condition solely through science and medical textbooks. I know of no better story to read, in order to understand what medicine can learn from fiction.

Competing interests None declared.
Provenance and peer review Commissioned; internally peer reviewed.

(C) Article author(s) (or their employer(s) unless otherwise stated in the text of the article) 2018. All rights reserved. No commercial use is permitted unless otherwise expressly granted.

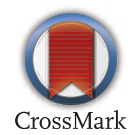

To cite Launer J. Postgrad Med J 2018;94:69-70.

Postgrad Med J 2018;94:69-70.

doi:10.1136/postgradmedj-2017-135487

\section{REFERENCES}

1 Maugham WS. Collected Stories. London: Everyman, 2004.

2 Williams WC. The Doctor Stories. New York: New Directions, 1984.

3 Chekhov A. Anton Chekhov's Short Stories (Norton Critical Edition). New York: Norton, 1979.

4 Schnitzler A. Dying. London: Pushkin press, 2006. 